\title{
Characterization of diverse natural variants of CYP102A1 found within a species of Bacillus megaterium
}

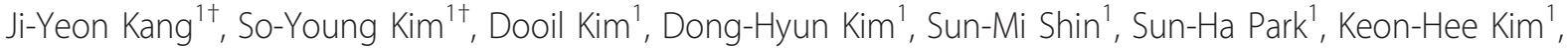 \\ Heung-Chae Jung ${ }^{2}$, Jae-Gu Pan ${ }^{2}$, Young Hee Joung ${ }^{1}$, Youn-Tae Chi ${ }^{1}$, Ho Zoon Chae ${ }^{1}$, Taeho Ahn ${ }^{3}$, Chul-Ho Yun ${ }^{1 *}$
}

\begin{abstract}
An extreme diversity of substrates and catalytic reactions of cytochrome P450 (P450) enzymes is considered to be the consequence of evolutionary adaptation driven by different metabolic or environmental demands. Here we report the presence of numerous natural variants of P450 BM3 (CYP102A1) within a species of Bacillus megaterium. Extensive amino acid substitutions (up to 5\% of the total 1049 amino acid residues) were identified from the variants. Phylogenetic analyses suggest that this P450 gene evolve more rapidly than the rRNA gene locus. It was found that key catalytic residues in the substrate channel and active site are retained. Although there were no apparent variations in hydroxylation activity towards myristic acid $\left(C_{14}\right)$ and palmitic acid $\left(C_{16}\right)$, the hydroxylation rates of lauric acid $\left(C_{12}\right)$ by the variants varied in the range of $>25$-fold. Interestingly, catalytic activities of the variants are promiscuous towards non-natural substrates including human P450 substrates. It can be suggested that CYP102A1 variants can acquire new catalytic activities through site-specific mutations distal to the active site.
\end{abstract}

\section{Introduction}

Cytochrome P450s (EC 1.14.14.1; P450 or CYP) are remarkably diverse oxygenation catalysts that are found throughout all classes of life. Although over 11,200 genes of P450s have been found in archaea, bacteria, fungi, plants, and animals (the Cytochrome P450 homepage, http://drnelson.uthsc.edu/P450.statsfile.html), their evolution is not clear. An extreme diversity of substrates and catalytic reactions is characteristic of P450s (Guengerich 2001) and is considered to be the consequence of evolutionary adaptation driven by different metabolic or environmental demands in different organisms. Although most bacterial P450s do not seem to be essential to basic metabolism, they have important roles in the production of secondary metabolites and in detoxication (Kelly et al. 2005).

P450 BM3 (CYP102A1) from Bacillus megaterium is a self-sufficient monooxygenase as it is fused to its redox partner, an eukaryotic-like diflavin reductase. Interestingly, sequence analysis for the P450 phylogenetic tree

\footnotetext{
* Correspondence: chyun@jnu.ac.kr

+ Contributed equally

'School of Biological Sciences and Technology, Chonnam National

University, Gwangju 500-757, Republic of Korea.

Full list of author information is available at the end of the article
}

suggested that the CYP102A1 clusters with the eukaryotic P450s but not with other prokaryotic P450s (Lewis et al. 1998). The natural substrates of CYP102A1 are long chain fatty acids $\left(\mathrm{C}_{12}\right.$ to $\left.\mathrm{C}_{20}\right)$, which are exclusively hydroxylated at the subterminal positions ( $\omega-1$ to $\omega-3)$ (Boddupalli et al. 1990). Furthermore, this enzyme exhibits the highest catalytic activity ever detected among P450 monooxygenase (Boddupalli et al. 1990). Engineered CYP102A1 mutants derived by directed evolution and rational design could oxidize several nonnatural substrates, including pharmaceuticals, shortchain hydrocarbons, and environmental chemicals (Yun et al. 2007; Stjernschantz et al. 2008; Seifert et al. 2009). The potential of engineered CYP102A1 for biotechnological applications has been recognized (Bernhardt 2006). Recently, it was reported that CYP102A1 can be developed as a potentially versatile biocatalyst for the generation of human P450 drug metabolites (Yun et al. 2007; Kim et al. 2009, 2010; Park et al. 2010; Sawayama et al. 2009; Whitehouse et al. 2009; Kim et al. 2011). Human P450 enzymes are responsible for the metabolism of about $75 \%$ of drugs used clinically (Williams et al. 2004; Guengerich 2003). Human drug metabolites are very

\section{SpringerOpen $^{\circ}$}

(C) 2011 Kang et al; licensee Springer. This is an Open Access article distributed under the terms of the Creative Commons Attribution License (http://creativecommons.org/licenses/by/2.0), which permits unrestricted use, distribution, and reproduction in any medium, provided the original work is properly cited. 
useful in evaluating a drug's efficacy, toxicity, and pharmacokinetics (Johnson et al. 2004; Atrakchi 2009; Leclercq et al. 2009). They can also be used as starting materials for drug candidates.

By using a systematic screening strategy, we found a number of natural variants of CYP102A1. Although there were no apparent variations in hydroxylation activity towards myristic acid $\left(\mathrm{C}_{14}\right)$ and palmitic acid $\left(C_{16}\right)$, the oxidation rates of lauric acid $\left(C_{12}\right)$ by the variants varied in the range of $>25$-fold. Some of the natural variants showed catalytic promiscuity towards non-natural substrates, particularly human P450 drug substrates. This study shows that diverse mutations are present in the gene of CYP102A1. Several specific residues for frequent mutations were found and the mutational frequency of reductase domains was much higher than that of heme domains.

\section{Materials and methods \\ Materials}

Isopropyl- $\beta$-D-thiogalactopyranoside (IPTG), glucose-6phosphate, glucose-6-phosphate dehydrogenase, $\delta$ aminolevulinic acid ( $\delta$-ALA), reduced $\beta$-nicotinamide adenine dinucleotide phosphate (NADPH), fatty acids, $\mathrm{N}, \mathrm{O}$-bis(trimethylsilyl)trifluoroacetamide (BSTFA), ferricyanide, phenacetin, acetaminophen, chlorzoxazone, coumarin, 7-ethoxycoumarin, and cytochrome $c$ were obtained from Sigma-Aldrich (St. Louis, MO).

\section{Bacterial strains}

Strains of B. megaterium used in this study were obtained from Korean Culture Center of Microorganisms (KCCM), Korean Collection for Type Cultures (KCTC), American Type Microbiology (ATCC), and the Institute of Fermentation, Osaka (IFO) (Table 1).

\section{PCR and cloning of CYP102A1 natural variants}

For DNA preparations, cells were grown in nutrient broth. After overnight growth at $37^{\circ} \mathrm{C}$, the cells were centrifuged, washed, lysed, and enzymatically treated to remove RNA and protein. The DNA preparation was then treated with phenol-chloroform (50:50) and ethanol-precipitated. The purity was evaluated by measuring UV absorbance. The variant genes from $B$. megaterium were amplified by polymerase chain reaction (PCR) using oligonucleotide primers and $B$. megaterium chromosomal DNA template. First, PCR was carried out in a $50 \mu \mathrm{l}$ reaction mixture containing template plasmid, forward primer BamHI-F (5'- AGCGGATCCATGACAATTAAAGAAATGCCTC-3') and reverse primer SacI-R (5'-ATCGAGCTCGTAGTTTGTAT-3'), dNTPs, and pfu polymerase. The PCR was carried out for 30 cycles consisting of $45 \mathrm{~s}$ of denaturation at $94^{\circ} \mathrm{C}, 45 \mathrm{~s}$ of annealing at $52^{\circ} \mathrm{C}$, and $90 \mathrm{~s}$ of extension at $72^{\circ} \mathrm{C}$. Next, PCR was
Table 1 Bacillus megaterium strains used in this study, and GenBank accession numbers for CYP102A1 variants, $16 S$ rRNA, and ITS sequences between 16S-23S sequences $^{a}$

\begin{tabular}{|c|c|c|c|c|}
\hline \multirow[b]{2}{*}{ Strain } & \multirow[b]{2}{*}{$\begin{array}{l}\text { Variant } \\
\text { Name }^{b}\end{array}$} & \multicolumn{3}{|c|}{ Accession Number } \\
\hline & & $\begin{array}{l}\text { Genomic } \\
\text { DNA }\end{array}$ & $\begin{array}{l}16 \mathrm{~S} \\
\text { rRNA }\end{array}$ & $\begin{array}{c}16 \mathrm{~S}-23 \mathrm{~S} \\
\text { intergenic }\end{array}$ \\
\hline KCCM 11745 & $102 \mathrm{~A} 1.1$ & $(J 04832)^{C}$ & FJ917385 & FJ969781 \\
\hline IFO 12108 & 102A 1.1 & $(J 04832)^{C}$ & FJ969756 & FJ969774 \\
\hline ATCC 14581 & $102 \mathrm{~A} 1.1$ & $(J 04832)^{c}$ & FJ969751 & FJ969767 \\
\hline KCCM 41415 & $102 \mathrm{~A} 1.1$ & $(J 04832)^{C}$ & FJ969762 & FJ969792 \\
\hline KCTC 3712 & $102 \mathrm{~A} 1.2$ & FJ899078 & FJ969764 & FJ969795 \\
\hline KCCM 12503 & $102 \mathrm{~A} 1.3$ & FJ899082 & FJ969761 & FJ969787 \\
\hline ATCC 15451 & 102A1.4 & FJ899085 & FJ969753 & FJ969768 \\
\hline ATCC 10778 & 102A1.5 & FJ899078 & FJ969746 & FJ969765 \\
\hline KCCM 11938 & $102 \mathrm{~A} 1.5$ & FJ899078 & FJ969760 & FJ969786 \\
\hline KCCM 11761 & $102 \mathrm{~A} 1.5$ & FJ899078 & FJ969757 & FJ969783 \\
\hline KCCM 11776 & $102 \mathrm{~A} 1.6$ & FJ899081 & FJ969758 & FJ969784 \\
\hline KCCM 11934 & $102 \mathrm{~A} 1.6$ & FJ899081 & FJ969759 & FJ969785 \\
\hline ATCC 14945 & 102A1.7 & FJ899084 & FJ969749 & FJ969766 \\
\hline ATCC 21916 & $102 \mathrm{~A} 1.8$ & FJ899092 & FJ969755 & FJ969772 \\
\hline KCTC 2194 & $102 \mathrm{~A} 1.8$ & FJ859036 & FJ969763 & FJ969794 \\
\hline ATCC 19213 & $102 \mathrm{~A} 1.9$ & FJ899091 & FJ969754 & FJ969769 \\
\hline ATCC 12872 & $\mathrm{QM} \mathrm{B1551^{d }}$ & $-e$ & $-e$ & $-e$ \\
\hline
\end{tabular}

${ }^{a}$ GenBank accession numbers (except J04832) were assigned to nucleotide sequences determined in this study. The corresponding CYP102A1 variant gene for each strain is listed.

${ }^{b}$ The CYP102A1 variants were named based on the amino acid similarity (Fig. 1a and Table 2).

'Previously known as the nucleotide sequence of P450 BM3 (CYP102A1) from B. megaterium (Ruettinger et al. 1989).

${ }^{d}$ Genetic Information regarding the CYP102A1 variant of B. megaterium QM B1551 (ATCC 12872) was obtained from the Whole Genome Sequencing of B. megaterium http://www.bios.niu.edu/b_megaterium/ and the variant was designated as QM B1551. We only used its genetic information to compare to those of other variants and did not study its biochemical and physical properties.

${ }^{e}$ Genetic information of B. megaterium QM B1551 (ATCC 12872) regarding its CYP102A1 variant, 16S rRNA, and ITS was obtained from the Whole Genome Sequencing of B. megaterium http://www.bios.niu.edu/b_megaterium/. Accession numbers were not provided.

carried out in a similar way by use of forward primer SacI-F (5'-ATACAAACTACGAGCTCGAT-3') and reverse primer XhoI-R (5'-ATCCTCGAGTTACCCAGCCCACACGTC-3'). The PCR product was digested with BamHI and SacI, and ligated into the $\mathrm{pCW}$ ori expression vector that had previously digested with the same restriction enzymes (Farinas et al. 2001). The amplified genes were subsequently cloned into the pCWBM3 BamHI/SacI vector at the BamHI/SacI restriction sites.

Because PCR amplification could lead to the introduction of random mutations and cloning of PCR products can fortuitously select the mutated sequences, all genes of CYP102A1 variants were PCR amplified a second time from genomic DNA and the sequences were directly determined without prior cloning. Exactly the 
same variations as those shown in Table 1 were again found, indicating that they were not artificially introduced during the PCR amplification.

\section{Sequencing and phylogenetic analysis of $16 \mathrm{~S}$ rRNA and ITS between $16 \mathrm{~s}$ and 23s rRNA}

The amplification of partial 16S rRNA genes was carried out using the primers 9F (5'-GAGTTTGATCCTGGCTCAG-3') and 1512R (5'-ACGGCTACCTTGTTACGACTT-3') (Ni et al. 2008). The amplification reaction $(25 \mu \mathrm{l})$ contained $50 \mathrm{ng} \mathrm{DNA}, 0.50 \mu \mathrm{M}$ of each primer, $250 \mu \mathrm{M}$ dNTPs, $1.5 \mathrm{mM} \mathrm{MgCl}_{2}$, and $1.25 \mathrm{U}$ pfu polymerase in the buffer supplied by the manufacturer. The PCR was carried out for initial denaturation at $95^{\circ} \mathrm{C}$ for $5 \mathrm{~min}$, followed by 30 cycles consisting of $95^{\circ} \mathrm{C}$ for $45 \mathrm{~s}$, $55^{\circ} \mathrm{C}$ for $45 \mathrm{~s}$, and $72^{\circ} \mathrm{C}$ for $90 \mathrm{~s}$ and final extension at $72^{\circ} \mathrm{C}$ for $10 \mathrm{~min}$. Amplification products $(10 \mu \mathrm{l})$ were electrophoresed in a $2 \%$ agarose gel and visualized under UV light after staining with ethidium bromide. Direct sequencing of the PCR products was performed with an ABI BigDye terminator v3.1 sequencing Ready Reaction kit.

One ITS region was amplified with primers $16 \mathrm{~S}-\mathrm{F}$ (5'-AAGTCGGTGGAGTAACCGT-3') and 23S-R (5' - TGTTAGTCCCGTCCTTCAT-3'). PCR reactions $(25 \mu \mathrm{l})$ contained $50 \mathrm{ng}$ DNA, $0.5 \mu \mathrm{M}$ of each primer, $250 \mu \mathrm{M}$ dNTPs, and $2.5 \mathrm{U}$ Taq DNA polymerase in the buffer supplied by the manufacturer. The PCR was carried out for initial denaturation at $95^{\circ} \mathrm{C}$ for $15 \mathrm{~min}$, followed by 35 cycles consisting of $95^{\circ} \mathrm{C}$ for $20 \mathrm{~s}, 52^{\circ} \mathrm{C}$ for $30 \mathrm{~s}$, and $72^{\circ} \mathrm{C}$ for $60 \mathrm{~s}$ and final extension at $72^{\circ} \mathrm{C}$ for $3 \mathrm{~min}$.

All sequencing procedures were repeated at least twice for each strain. The $16 \mathrm{~S}$ rRNA gene sequences and the 16S-23S rRNA intergenic spacers were compared to sequences in the GenBank database using BLAST (Altschul et al. 1990). The sequences were aligned by using the CLUSTAL W program (Thompson et al. 1997).

\section{Expression and purification of CYP102A1 natural variants} Plasmids were transformed into E. coli DH5 $\alpha$ F'-IQ cell. Overnight cultures $(20 \mathrm{ml})$ grown in Luria-Bertani broth with ampicillin $(100 \mu \mathrm{g} / \mathrm{ml})$ selection at $37^{\circ} \mathrm{C}$ were used to inoculate a $250 \mathrm{ml}$ culture of Terrific broth containing $100 \mu \mathrm{g} / \mathrm{ml}$ ampicillin, $1.0 \mathrm{mM}$ thiamine, trace elements, $50 \mu \mathrm{M} \mathrm{FeCl}_{3}, 1.0 \mathrm{mM} \mathrm{MgCl}$, and $2.5 \mathrm{mM}\left(\mathrm{NH}_{4}\right)_{2} \mathrm{SO}$. Cells were grown at $37^{\circ} \mathrm{C}$ and $250 \mathrm{rpm}$ to an $\mathrm{OD}_{600}$ of between 0.6-0.8. Protein expression was induced by adding $1.0 \mathrm{mM}$ IPTG and $1.5 \mathrm{mM} \delta$-ALA, and cultures were grown at $28^{\circ} \mathrm{C}$ and $200 \mathrm{rpm}$ for $50 \mathrm{~h}$. The cells were harvested by centrifugation $\left(15 \mathrm{~min}, 5,000 \mathrm{~g}, 4^{\circ} \mathrm{C}\right)$. The cell pellet was resuspended in TES buffer $[100 \mathrm{mM}$ Tris- $\mathrm{HCl}$ (pH 7.6), $500 \mathrm{mM}$ sucrose, $0.5 \mathrm{mM}$ EDTA] and lysed by sonication (Sonicator, Heat Systems - Ultrasonic, Inc.). After the lysate was centrifuged at 100,000 $\mathrm{g}$ (90 min, $4^{\circ} \mathrm{C}$ ), the soluble cytosolic fraction was collected and used for the activity assay. The cytosolic fraction was dialyzed against $50 \mathrm{mM}$ potassium phosphate buffer $(\mathrm{pH} 7.4)$ and stored at $-80^{\circ} \mathrm{C}$ until use. The $\mathrm{P} 450$ concentration was determined by $\mathrm{Fe}^{2+}-\mathrm{CO}$ versus $\mathrm{Fe}^{2+}$ difference spectra (Omura and Sato 1964).

\section{Binding affinity of fatty acids to CYP102A1 variants}

To determine dissociation constants $\left(K_{\mathrm{d}}\right.$ values) of fatty acids to the CYP102A1 variants, spectral binding titration was performed for enzymes with saturated fatty acids (lauric acid, myristic acid, and palmitic acid). The $K_{\mathrm{d}}$ values of substrates to the CYP102A1 variants were determined (at $23^{\circ} \mathrm{C}$ ) by titrating $2.0 \mu \mathrm{M}$ enzyme with the ligand, in a total volume of $1.0 \mathrm{ml}$ of $100 \mathrm{mM}$ potassium phosphate buffer ( $\mathrm{pH}$ 7.4). The ligands were dissolved in dimethylsulfoxide and final dimethylsulfoxide concentrations were $<1 \%(\mathrm{v} / \mathrm{v})$. Absorbance increases at $390 \mathrm{~nm}$ and decreases at $420 \mathrm{~nm}$ as the substrate concentration increases (Lentz et al. 2001). The absorption difference between $390 \mathrm{~nm}$ and $420 \mathrm{~nm}$ was plotted against the substrate concentration (up to $1.0 \mathrm{mM}$ ) (Kim et al. 2008a, b). The $K_{\mathrm{d}}$ values were determined from plots of induced absorption changes versus ligand concentration. The data were fitted using a standard hyperbolic function or (where the $K_{\mathrm{d}}$ value was within 5-fold of the P450 concentration) a quadratic function for tight-binding ligands, as described elsewhere (Girvan et al. 2010).

\section{Assay of fatty acid hydroxylation by natural variants and distribution of hydroxylated products}

Metabolites were generated by incubation of $1.0 \mathrm{mM}$ fatty acids and P450 enzyme (100 pmol) in a $1.0 \mathrm{ml}$ volume of $100 \mathrm{mM}$ potassium phosphate ( $\mathrm{pH} 7.4$ ) for $20 \mathrm{~min}$ at $37^{\circ} \mathrm{C}$ (Gustafsson et al. 2004). An aliquot of a NADPH-generating system was used to initiate reactions; final concentrations were $10 \mathrm{mM}$ glucose 6-phosphate, $0.5 \mathrm{mM} \mathrm{NADP}^{+}$, and $1 \mathrm{IU} / \mathrm{ml}$ yeast glucose 6-phosphate dehydrogenase. The reactions were terminated with a 2 -fold excess of icecold dichloromethane. After centrifugation of the reaction mixture, the organic solvent was removed under a gentle stream of nitrogen and the residue was dissolved in BSTFA $(50 \mu \mathrm{l})$ containing trimethylchorosilane $(1 \%, \mathrm{v} / \mathrm{v})$. The solution was transferred to a glass vial and incubated at $75^{\circ} \mathrm{C}$ for $20 \mathrm{~min}$ to yield trimethylsilylated products. To determine the regioselectivity of hydroxylated products of fatty acids at the $\omega-1, \omega-2$, and $\omega-3$ positions, GC/MS analysis was carried out on a Shimadzu QP2010 (column length, $30 \mathrm{~m}$; internal diameter, $0.25 \mathrm{~mm}$; film thickness, $0.1 \mu \mathrm{m}$ ), with electron-impact ionization. The GC oven temperature was programmed for $1 \mathrm{~min}$ at $70^{\circ} \mathrm{C}$ followed by an increase to $170^{\circ} \mathrm{C}$ at $25^{\circ} \mathrm{C} / \mathrm{min}$, to $200^{\circ} \mathrm{C}$ at $5^{\circ} \mathrm{C} / \mathrm{min}$, and to $280^{\circ} \mathrm{C}$ at $20^{\circ} \mathrm{C} / \mathrm{min}$. The oven was finally held at $280^{\circ} \mathrm{C}$ for $5 \mathrm{~min}$. The MS source and interface were 
maintained at 250 and $280^{\circ} \mathrm{C}$, respectively, and a solvent delay of $4 \mathrm{~min}$ was used. The mass spectra were collected using electron ionization at $70 \mathrm{eV}$. The products were identified by their characteristic mass fragmentation patterns (Lentz et al. 2001). Turnover numbers of the hydroxylation of fatty acids (lauric acid, myristic acid, palmitic acid) by the variants of CYP102A1 were determined by a GC-FID detector (Shimadzu GC2010 with FID detector). Essentially the same procedure was used for the regioselectivity of the hydroxylated products of fatty acid oxidation. The distribution of products was based on the relative peak area of the chromatogram of GC using hydroxylated products at $\omega$ position as standards.

NADPH oxidation activities supported by natural variants Reaction mixtures contained $1.0 \mathrm{mM}$ fatty acid and P450 enzyme $(25 \mathrm{nM})$ in a $1 \mathrm{ml}$ volume of $100 \mathrm{mM}$ potassium phosphate $(\mathrm{pH} 7.4)$. Initial rates of fatty acid-induced NADPH oxidation were measured by monitoring the absorption change at $340 \mathrm{~nm}\left(\varepsilon_{340}=\right.$ $6,220 \mathrm{M}^{-1} \mathrm{~cm}^{-1}$ ) after NADPH was added at a concentration of $200 \mu \mathrm{M}$. Rates of change in $A_{340}$ absorbance were converted into activity units (moles of NADPH oxidized per minute per mole of enzyme) (Noble et al. 1999).

\section{Enzymatic activities of reductase domains of natural variants}

For the reductase assay, two different types of reductase substrates were used. One was a chemical substrate, ferricyanide, and the other was cytochrome $c$, which is a protein substrate, as described previously (Gustafsson et al. 2004). Assays for reductase domain-dependent electron transfer to exogenous electron acceptors (ferricyanide or cytochrome $c$ ) were also performed at $37^{\circ} \mathrm{C}$ in potassium phosphate ( $\mathrm{pH} 7.4$ ), with $2.5 \mathrm{nM}$ enzyme, $200 \mu \mathrm{M}$ NADPH, and electron acceptors $(500 \mu \mathrm{M}$ ferricyanide; $100 \mu \mathrm{M}$ cytochrome $c$ ). Ferricyanide reduction was measured at $420 \mathrm{~nm}\left(\varepsilon_{420}=1.02 \mathrm{mM}^{-1} \mathrm{~cm}^{-1}\right.$ for the ferricyanide reduction product) and cytochrome $c$ reduction was measured at $550 \mathrm{~nm}\left(\varepsilon_{550}=21.0 \mathrm{mM}^{-1} \mathrm{~cm}^{-1}\right.$ for the reduced cytochrome $c$ ).

\section{Thermal stability}

To analyze enzyme stability, enzymes $(2.0 \mu \mathrm{M})$ were incubated at different temperatures between 25 and $70^{\circ} \mathrm{C}$ for $20 \mathrm{~min}$ with subsequent cooling to $4^{\circ} \mathrm{C}$ in a PCR thermocycler (Eiben et al. 2007). The stability of the heme domain was calculated from heat-inactivation curves of CO-binding difference spectra (Omura and Sato 1964). The stability of the reductase domain was calculated from the reduction of ferricyanide catalyzed by reductase activity, as described above.
Catalytic activity assays towards human P450 substrates Purified natural variants of CYP102A1 were characterized for human P450 enzyme activities using specific substrates as summarized elsewhere (Yun et al. 2006): phenacetin $O$-deethylation for human P450 1A2; 7-ethoxycoumarin (7-EC) $O$-deethylation for human P450s 1A2, 2A6, and 2E1; 7-ethoxy-4-trifluoromethylcoumarin (7-EFC) $O$-deethylation for P450s $1 \mathrm{~A} 2$ and 2B6; chlorzoxazone $6 \beta$-hydroxylation for P450 2E1; coumarin 7-hydroxylation for P450 2A6.

\section{Sequence analysis}

DNA sequences of CYP102A1 variants, 16S rRNA sequences, and the ITS alleles between $16 \mathrm{~S}$ and $23 \mathrm{~S}$ rRNA genes obtained in this study were deposited in GenBank. The accession numbers are provided at Table 1. Genetic information of B. megaterium QM B1551 (ATCC 12872) regarding the CYP102A1 variant, $16 \mathrm{~S}$ rRNA, and ITS was obtained from the homepage of Whole Genome Sequencing of B. megaterium http://www.bios.niu.edu/ b_megaterium/.

The sequences were aligned using the MEGA 3.1 program (Molecular Evolutionary Genetic Analysis) (http://www.megasoftware.net/mega_dos.html). The size of CYP102A1 variants was 1,049 amino acids (Additional file 1). ITS (338 nucleotides) between $16 \mathrm{~S}$ and 23S rRNA genes of $B$. megaterium was analyzed in this study. Phylogenetic trees were conducted by the neighbor-joining method using the MEGA 3.1 program. Bootstrap analysis of the neighbor-joining data, using 1,000 resamplings, was carried out to evaluate the validity and reliability of the tree topology.

\section{Nucleotide sequence accession numbers}

The nucleotide sequences determined in this study have been deposited in the GenBank database (Table 1): FJ859036, FJ899078, FJ899080 to FJ899082, FJ899084, FJ899085, FJ899091, and FJ899092 for CYP102A1 variants; FJ917385, FJ969746, FJ969749, FJ969751, and FJ969753 to FJ969764 for $16 \mathrm{~S}$ rRNA genes of B. megaterium; FJ969765 to FJ969769, FJ969772, FJ969774, FJ969781, FJ969783 to FJ969787, FJ969792, FJ969794, FJ969795 for ITS of 16S-23S rRNA genes of B. megaterium.

\section{Results}

\section{Natural variants of CYP102A1 within a species of $B$.} megaterium

Among 16 different strains of B. megaterium, 12 strains have natural genetic variants of CYP102A1 (Table 1). As some of them shared exactly the same DNA sequences, there were ultimately nine different types of CYP102A1 natural variants (Figure 1a, Table 1 and 2), including four previously reported variants (CYP102A1.1) (Ruettinger 
et al. 1989). Amino acid sequences of the CYP102A1 variants showed more than 96\% identity with CYP102A1.1 (Table 2 and Additional file 1). The amino acid differences among the variants included 20 residues (CYP102A1.3, 20/1049, 1.9\%) to 33 residues (CYP102A1.7, CYP102A1.8, CYP102A1.9; 33/1049, 3.1\%) among a total of 1,049 amino acids (Table 2). Phylogenetic analyses of the amino acid sequences of CYP102A1 variants showed that three variants are closely related to CYP102A1.1 and five variants are distinct from it (Figure 1a). Among the total 55 mutated amino acid residues, those located in the reductase domains (residues 474-1049) (45 of 55, 82\%) occurred at a much higher frequency than in heme domain
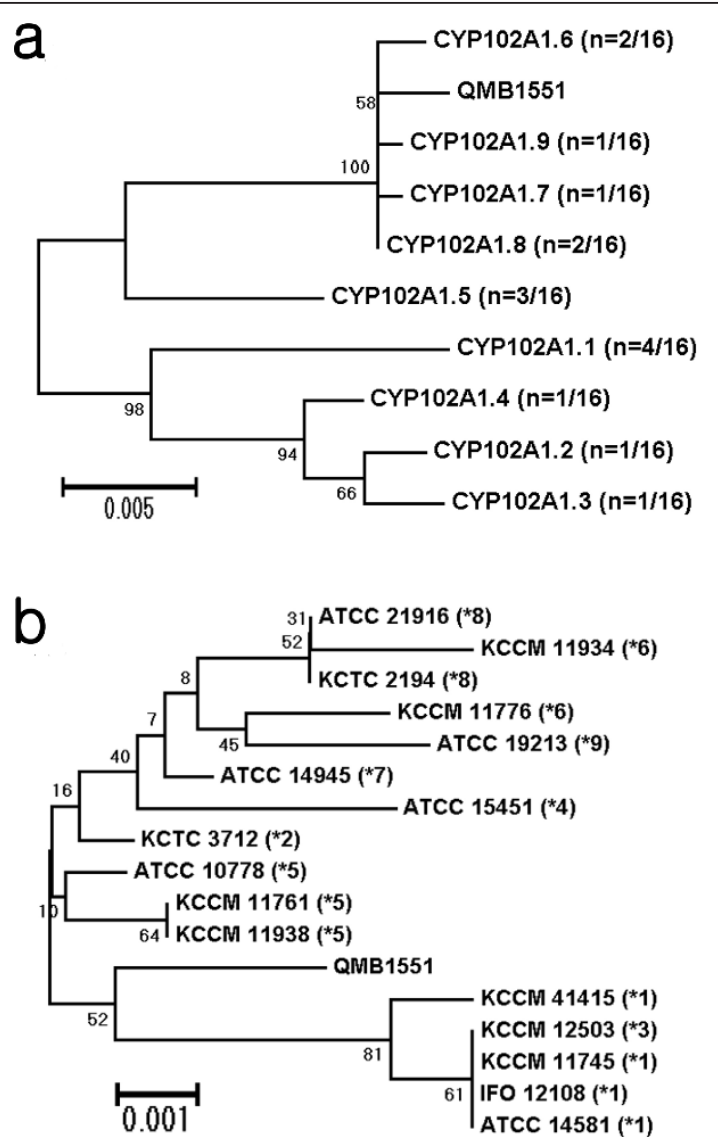

Figure 1 Summarized phylogeny of CYP102A1 natural variants and intergenic sequence (ITS) alleles from $B$. megaterium strains. (a) Phylogenetic analyses of CYP102A1 variants are based on the amino acid substitutions (Table 2 and Fig. S1) and silent mutations are excluded. Relative abundances are shown in parentheses. (b) Phylogenetic analyses of $B$. megaterium strains, which express CYP102A1, were based on the ITS gene sequences. The CYP102A1 variant expressed by each strain is shown as a number with an asterisk in parentheses. Numbers on tree branches show the percent bootstrap support for all branches important for interpretation. Nodes with bootstrap values of 1,000 resamplings (expressed by percentages) are indicated and the bar scales represent the substitution of amino acids (a) or nucleotides (b) per site. (residues 1-473) (10 of 55, 18\%) (Table 2). Interestingly, no substitutions in the amino acid residues of the active site or substrate channel (Ravichandran et al. 1993; Li and Poulos 1997) were seen among the 55 substitutions.

\section{Phylogenic analysis of bacterial strains and natural variants}

The 16S rRNA gene has been the molecular standard in studying evolutionary relationships among bacteria (Woese et al. 1990). Although DNA sequences of the $16 \mathrm{~S}$ rRNA genes of $16 \mathrm{~B}$. megaterium strains are well conserved ( 2 nucleotides are variable among a total of 1,394 nucleotides, 99.9\% identity) (Figure 2a), the intergenic sequence (ITS_ alleles between 16S and 23S rRNA genes, which reflect the evolution of the bacterial strains (Gürtler 1999), showed 7 nucleotide variations among a total of 338 nucleotides (98.8\% identity) (Figure 2b). Interestingly, the phylogenetic tree of ITS alleles was quite different from that of CYP102A1 natural variants. RNA analyses showed that the evolutionary profile of CYP102A1 variants is different from that of host strains (Figure 1).

\section{Biochemical characterization of the natural variants}

The biochemical properties of the variants were examined. All CYP102A1 variants could bind to saturated fatty acids in the range of 12-16 carbons with a general preference for long fatty acids (Figure 3a). The affinity of the variants to the fatty acids was quite different from that of CYP102A1.1 in the range of $>50$-fold for palmitic acid. However, the variations were less than 5-fold for lauric acid and myristic acid.

Although there were no apparent variations in hydroxylation activity towards myristic acid $\left(\mathrm{C}_{14}\right)$ and palmitic acid $\left(C_{16}\right)$, the oxidation rates of lauric acid $\left(C_{12}\right)$ by the variants varied in the range of $>25$-fold (Figure $3 \mathrm{~b}$ ). However, most of them did not show apparent changes in regioselectivity towards fatty acids (Additional file 2). For all fatty acids $\left(C_{12}, C_{14}, C_{16}\right)$ tested here, there were no apparent variations of regioselectivity among a set of CYP102A1 variants. CYP102A1 variants showed a preference for hydroxylation at the $\omega-1$ position of lauric acid, and myristic acid, and at the $\omega-2$ position for palmitic acid. Fatty acid-dependent NADPH oxidation rates by the variants were also determined in the presence of lauric, myristic, and palmitic acids (Kitazume et al. 2007) (Figure 3c). We could not find a direct correlation between NADPH oxidation and product formation of hydroxylated fatty acids.

The reductase activity towards ferricyanide was quite dependent on the type of CYP102A1 variant (Additional file 3). Variant CYP102A1.3 showed a 3-fold higher activity than that of CYP102A1.1. In the case of cytochrome $c$, variant CYP102A1.2 had the highest activity, 
Table 2 Sequence variations of CYP102A1 variants ${ }^{a}$

\begin{tabular}{|c|c|c|c|c|c|c|c|c|c|c|c|}
\hline \multicolumn{12}{|c|}{ CYP102A1 Variants } \\
\hline & Mutated Amino acid & Change of Nucleotide & $* 2$ & $* 3$ & $* 4$ & $*_{5}$ & *6 & *7 & $* 8$ & $* 9$ & QMB1551 \\
\hline & $\mathrm{T} 2 \mathrm{P}$ & $4 A>C$ & & & & & & & & & + \\
\hline \multirow[t]{11}{*}{ Heme domain } & V27I & $79 \mathrm{G}>\mathrm{A}$ & + & & + & & + & + & + & + & + \\
\hline & A29T & $85 G>A$ & + & & + & & + & + & + & + & + \\
\hline & V128I & $382 \mathrm{G}>\mathrm{A}$ & + & & + & + & + & + & + & + & + \\
\hline & A136T & $406 G>A$ & + & & + & & + & + & + & + & + \\
\hline & E208D & $624 \mathrm{~A}>\mathrm{C}$ & & & & + & & & & & \\
\hline & $\mathrm{A} 222 \mathrm{~T}$ & $664 G>A$ & & & & & & & & & + \\
\hline & A296T & $886 G>A$ & + & & + & & & & & & \\
\hline & D370E & $1110 C>A$ & + & & + & & & & & & \\
\hline & K453Q & $1357 A>C$ & & & & + & + & + & + & + & + \\
\hline & T464R & $1392 \mathrm{~T}>\mathrm{A}$ & & & & + & + & + & + & + & + \\
\hline & V471E & $1413 A>G$ & & & & + & + & + & + & + & + \\
\hline \multirow[t]{34}{*}{ Reductase domain } & K474T & $1422 G>C$ & & & & + & + & + & + & + & + \\
\hline & A475V & $1424 C>T$ & + & + & + & + & + & + & + & + & + \\
\hline & Q513R & $1539 G>A$ & & & & & & + & & & \\
\hline & $\mathrm{R} 526 \mathrm{P}$ & $1578 \mathrm{C}>\mathrm{T}$ & & & & & + & & & & \\
\hline & Q547E & $1639 C>G$ & & & & & + & + & + & + & + \\
\hline & E559D & $1677 A>C$ & + & + & + & & & & . & . & \\
\hline & L590F & $1794 C>A$ & & & & & & & & + & \\
\hline & A591S & $1771 G>T$ & & & & + & & & & & \\
\hline & D600E & $1800 C>A$ & & & & + & + & + & + & + & + \\
\hline & V625L & $1873 G>T$ & & & & + & + & + & + & + & + \\
\hline & D632N & $1894 G>A$ & & & & + & 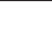 & - & . & . & 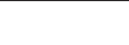 \\
\hline & D638E & $1914 \mathrm{~T}>\mathrm{A}$ & & & & 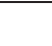 & + & + & + & + & + \\
\hline & K640A & $1920 \mathrm{~A}>\mathrm{T}$ & & & & + & + & + & + & + & + \\
\hline & A652S & $1954 \mathrm{G}>\mathrm{T}$ & & & & & & . & . & . & + \\
\hline & G661R & $1981 G>C$ & & & & & + & + & + & + & + \\
\hline & T665A & $1993 A>G$ & + & + & + & + & + & + & + & + & + \\
\hline & Q675K & $2023 C>A$ & & & & & + & + & + & + & + \\
\hline & P676L & $2027 C>T$ & + & + & & & & & 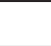 & 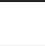 & \\
\hline & A679E & $2036 C>A$ & + & + & + & & & & & & \\
\hline & E688A & $2063 A>C$ & + & + & + & & & & . & & . \\
\hline & $\mathrm{T} 716 \mathrm{~A}$ & $2146 A>G$ & & & & & + & + & + & + & + \\
\hline & A717T & $2149 G>A$ & & & & + & + & + & + & + & + \\
\hline & A742G & $2225 C>G$ & + & + & + & + & + & + & + & + & + \\
\hline & A783V & $2348 C>T$ & & & & & + & + & + & + & + \\
\hline & A796T & $2386 G>A$ & & & & + & & & & & \\
\hline & K814E & $2440 A>G$ & + & + & + & + & + & + & + & + & + \\
\hline & $1825 \mathrm{M}$ & $2474 A>G$ & & & & + & + & + & + & + & + \\
\hline & R826S & $2476 C>A$ & + & + & & & & & & & \\
\hline & $\mathrm{R} 837 \mathrm{H}$ & $2510 G>A$ & + & + & & & & & & & \\
\hline & E871N & $2613 G>T$ & + & + & + & & + & + & + & + & + \\
\hline & $1882 \mathrm{~V}$ & $2644 A>G$ & + & + & + & + & + & + & + & + & + \\
\hline & E888G & $2663 A>G$ & + & + & + & + & + & + & + & + & + \\
\hline & D894G & $2681 A>G$ & & & & & + & + & + & + & + \\
\hline & P895S & $2683 C>T$ & + & + & + & & & & & & \\
\hline
\end{tabular}


Table 2 Sequence variations of CYP102A1 variants ${ }^{a}$ (Continued)

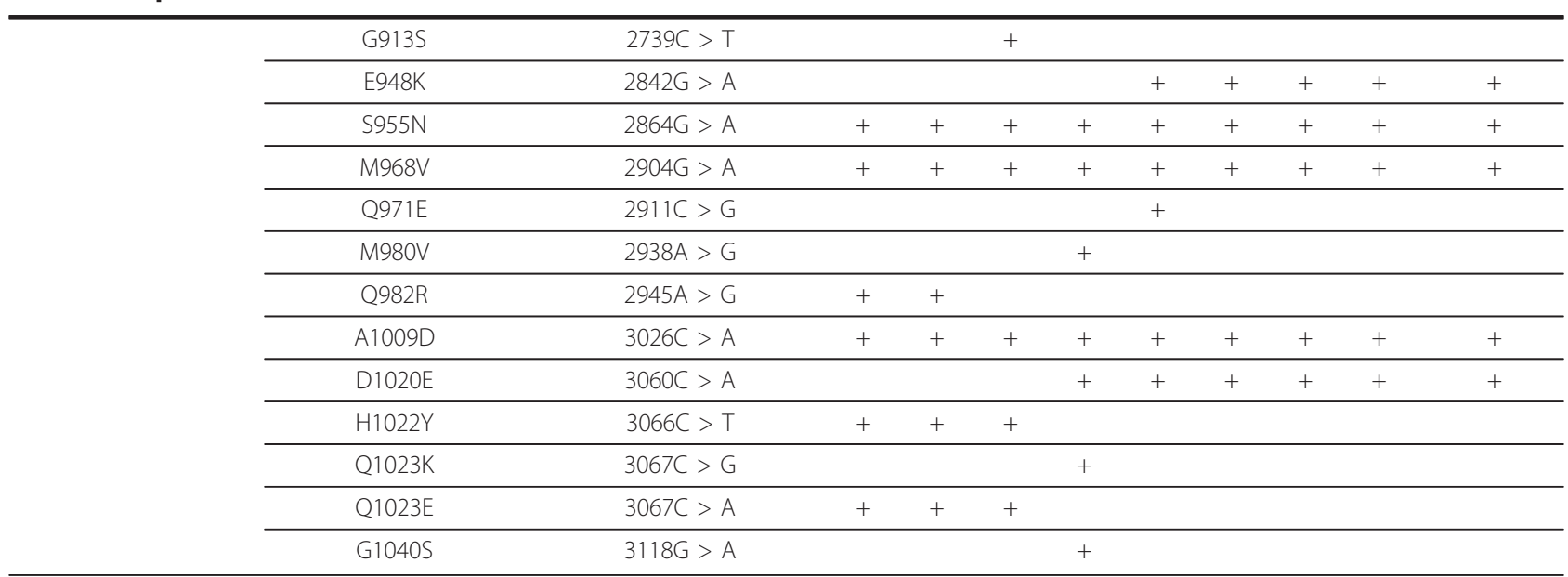

${ }^{a}$ Variations of amino acids and nucleotides in CYP102A1 variants $\left({ }^{*} 2 *^{*} 9\right)$ relative to CYP102A1.1 (P450 BM3) $\left({ }^{*} 1\right)$ are shown by a (+) mark. Information regarding the CYP102A1 variant (designated as QMB1551) of B. megaterium QM B1551 (ATCC 12872) was obtained from the Whole Genome Sequencing of B. megaterium $\mathrm{http} / / /$ www.bios.niu.edu/b_megaterium/. We only used its genetic information to compare to those of other variants. Blanks mean no change of amino acids or nucleotides.

which was 3-fold higher than that of CYP102A1.1. These variations seem to be related to the variations in amino acid sequence.

\section{Thermal stability of heme and reductase domains in the natural variants}

The thermal stability of the heme and reductase domains was examined. The $T_{50}$ value of the CYP102A1.1 heme domain was $51^{\circ} \mathrm{C}$ and the variants showed similar $T_{50}$ values in the range of $51-55^{\circ} \mathrm{C}$ (Figure 4). The $T_{50}$ value of the CYP102A1.1 reductase domain was $45^{\circ} \mathrm{C}$ and the $T_{50}$ values of the variants' reductase domains were in the range of $40-48^{\circ} \mathrm{C}$. CYP102A1.5 $\left(T_{50}, 48^{\circ} \mathrm{C}\right)$ showed the highest thermal stability among CYP102A1 variants. The thermal stabilities of the reductase domains were much lower than those of the heme domains of the CYP102A1 variants.

\section{Catalytic promiscuity of the natural variants towards non- natural substrates}

It is known that wild-type and several mutants of CYP102A1 could oxidize several human P450 substrates, including pharmaceuticals (Yun et al. 2007). We examined the catalytic promiscuity of the CYP102A1 variants towards non-natural substrates. They showed quite distinct catalytic activities towards typical human P450 substrates including drugs (Figure 5). CYP102A1.7 could oxidize all human P450 substrates tested here. Although the oxidation rates of the variants for all tested human P450 substrates were fairly low $\left(<0.4 \mathrm{~min}^{-1}\right)$, we detected potential evidence for the evolvability of P450 catalytic activities. Low catalytic activity is an intrinsic property of human P450 enzymes (Guengerich 2005).
This result indicates that the variants show catalytic promiscuity towards non-natural substrates.

\section{Discussion}

The current study provides a glimpse into P450 diversity in bacteria. Extensive diversity of P450 genes has been found in bacteria, including a large set of strains of the genus Bacillus (Porwal et al. 2009). As we begin to survey the variants of bacterial P450 enzymes through a systematic approach with $B$. megaterium strains, there are exciting opportunities for studying the catalytic capabilities and the metabolic functions of the P450 monooxygenase systems. This work shows the presence of a number of $\mathrm{P} 450$ natural variants within a species of B. megaterium. Multiple amino acid substitutions (up to 4 among 528 amino acids of Candida albicans) in a fungal CYP51 (Kelly et al. 2005) and a large number of alleles in human P450 (Human Cytochrome P450 Allele Nomenclature Committee; http://www.cypalleles.ki.se/) and human NADPH-P450 reductase (Huang et al. 2008) genes were found. However, the diversity of a P450 gene within a species is much lower in these species than in B. megaterium CYP102A1.

Phylogenetic analysis suggests that CYP102A1 gene could have evolved more rapidly than the rRNA gene locus of the host strains under the selective pressures of their environments. For example, B. megaterium strains IFO 12108 (and KCCM 11745) and KCCM 12503 have exactly the same $16 \mathrm{~S}$ rRNA genes and ITS, but they express different variants of CYP102A1.1 and CYP102A1.3, respectively (Figure $1 \mathrm{~b}$ and 2). Given the diversification of ITS alleles that accompanies the strain evolution of B. megaterium, the distribution of CYP102A1 


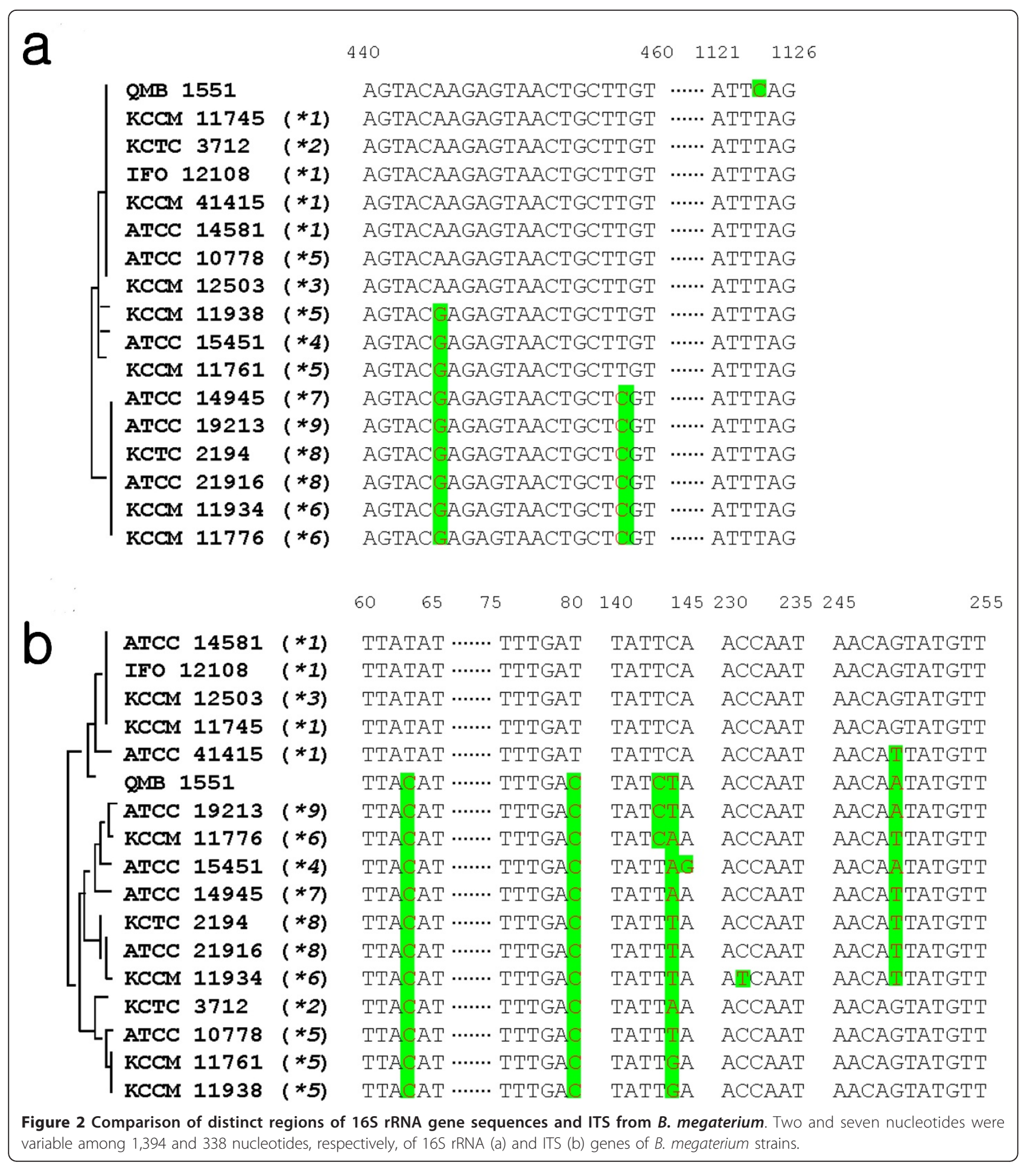

variants should uniquely define particular clades (Figure 1 and 2).

The reductase domains of CYP102A 1 variants are more divergent than heme domains (Table 2 and Additional File 1). However, binding sites of heme, FMN, and FAD, which are essential cofactors for oxidation activities, are well conserved except for a few residues of the FAD binding site of CYP102A1. Substitutions of amino acids in reductase domains of CYP102A1 variants occurred at high frequency $(7.8 \%$ of total amino acid residues). Mutations at the reductase domain may influence the monooxygenase activity of heme domain by 


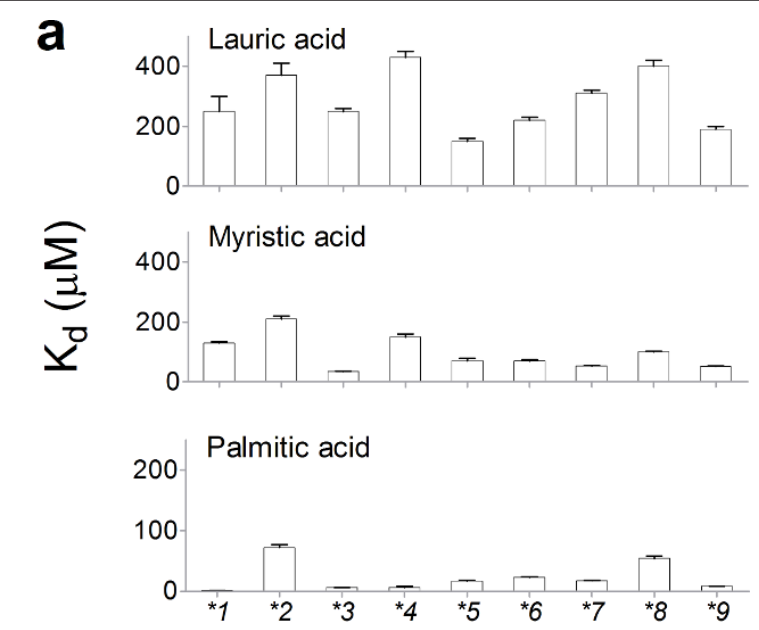

b
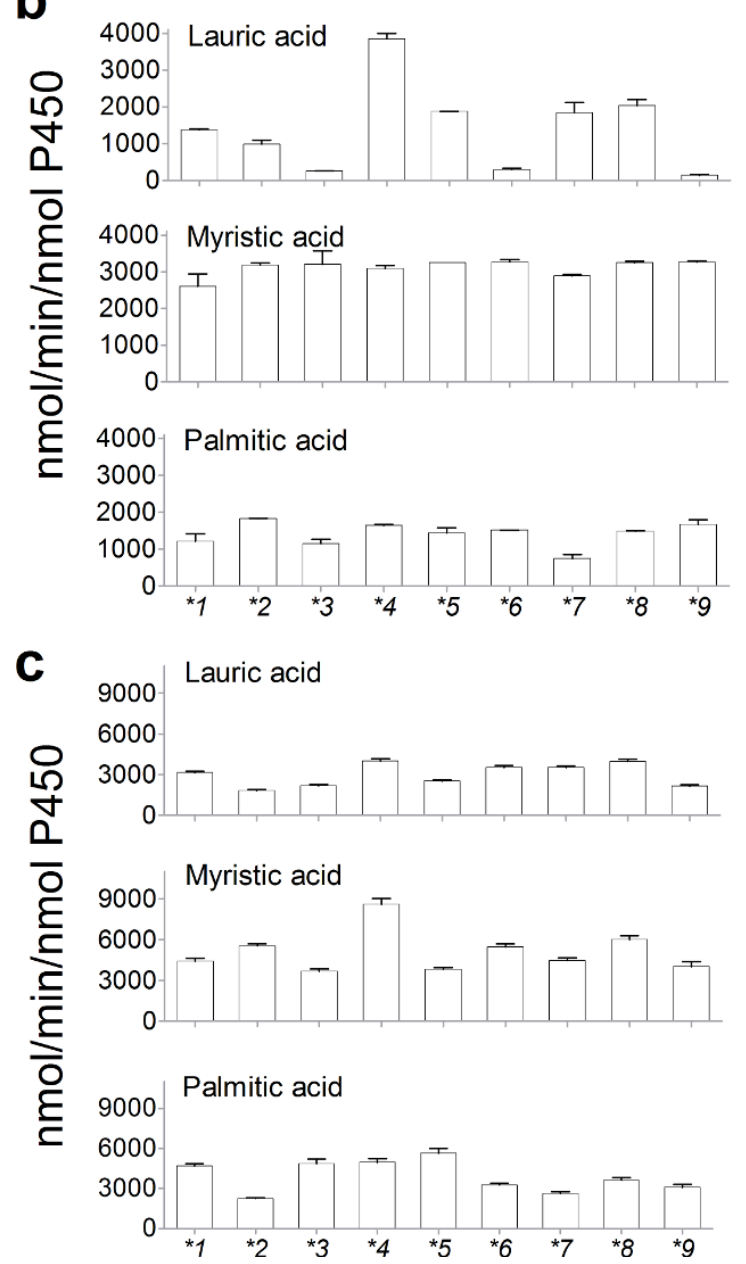

Figure 3 Biochemical properties of natural variants. (a) Dissociation constants ( $K_{d}$ values) of substrates (lauric acid, myristic acid, and palmitic acid) to CYP102A1 natural variants. (b) Turnover numbers of the hydroxylation of fatty acids (lauric acid, myristic acid, palmitic acid) by the variants of CYP102A1. (c) Rates of fatty aciddependent NADPH oxidation by the variants of CYP102A1.

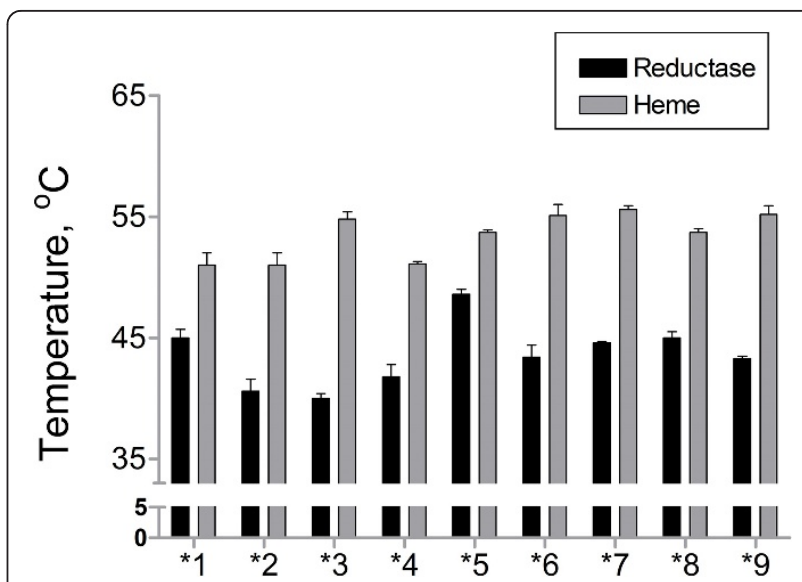

Figure 4 Thermal stability for each domain of CYP102A1 variants. Enzymes $(2 \mu \mathrm{M})$ were incubated at different temperatures between 25 and $70^{\circ} \mathrm{C}$ for 20 min with subsequent cooling to $4^{\circ} \mathrm{C}$ in a PCR thermocycler. The stability of the heme domain was calculated from heat-inactivation curves of CO-binding difference spectra. The stability of the reductase domain was calculated from the reduction of ferricyanide catalyzed by reductase activity.

controlling electron transfer process from reductase domain to heme domain. The changes in activity due to the mutations might give the organism a selective advantage for the evolutionary adaptation driven by different metabolic or environmental demands. In addition, the results of thermal stability (Figure 4) suggest that the higher mutation rate of the CYP102A1 reductase domain might affect the thermal stability of the reductase domains.

The occurrence of multiple amino acid substitutions appears to be common in CYP102A1 natural variants, although it is unclear as yet whether all identified mutations are important for substrate affinity, thermal stability, catalytic activities, and their promiscuity to non-natural substrates. It is found that wild-type CYP102A1 can catalyze the hydroxylation of chlorzoxazone, aniline and $p$-nitrophenol, as well as the $N$-dealkylation of propranolol and the dehydrogenation of nifedipine. These chemicals are typical substrates of human P450s 2E1, 2D6, 1A2 and $3 \mathrm{~A} 4$, which are the main drug-metabolizing enzymes. The catalytic activities of P450 BM3 are either comparable or higher than those measured for the human enzymes towards these smaller and non-physiological substrates. These results suggested the possibility to obtain fine chemicals including human drug metabolites by using CYP102A1 (Yun et al. 2007 and references therein). It should also be noted that highly active mutants of CYP102A1.1 (P450 BM3), which were obtained by directed evolution using random mutagenesis, towards non-natural substrates such as short-chain 


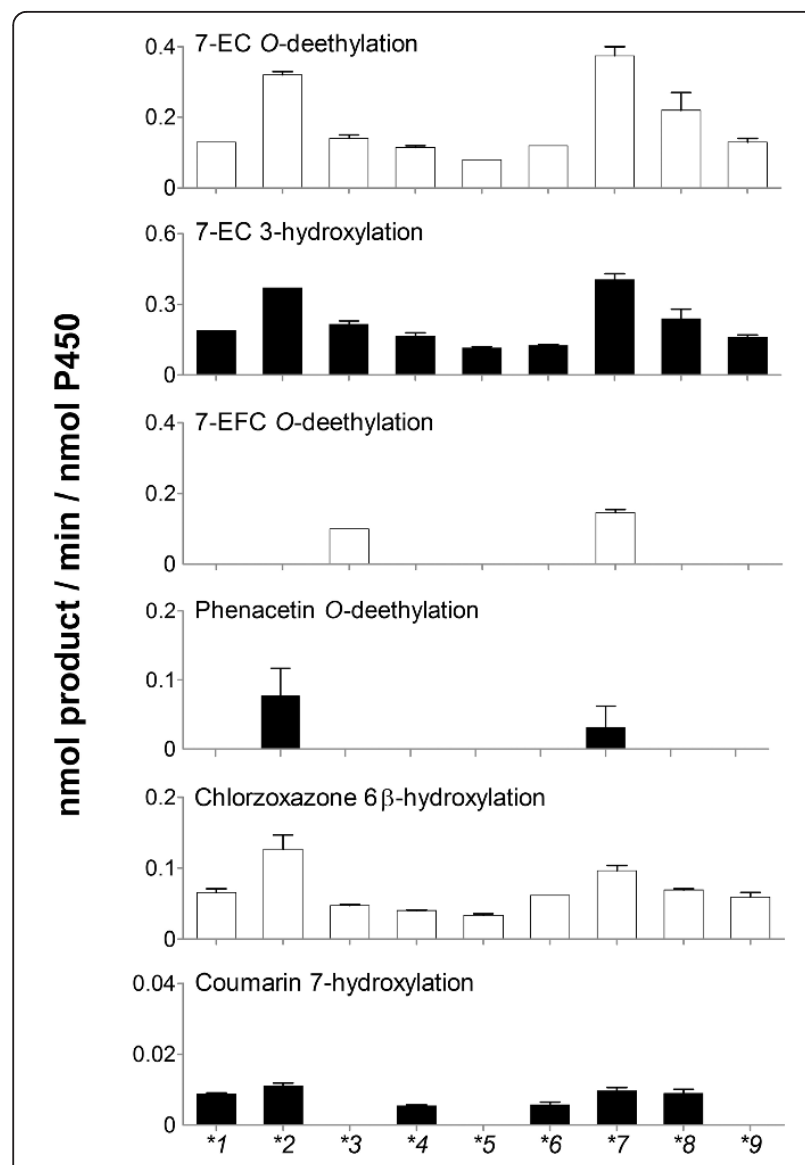

Figure 5 Catalytic promiscuity of natural variants of CYP102A1 towards human P450 substrates. Purified natural variants of CYP102A1 were characterized for human P450 enzyme activities using specific substrates: phenacetin O-deethylation for P450 1A2; 7-ethoxycoumarin (7-EC) O-deethylation for P450s 1A2, 2A6, and 2E1; 7-ethoxy-4-trifluoromethylcoumarin (7-EFC) O-deethylation for P450s $1 \mathrm{~A} 2$ and 2B6; chlorzoxazone $6 \beta$-hydroxylation for P450 2E1; coumarin 7-hyroxylation for P450 2A6. Data are shown as the means \pm SEM.

hydrocarbons (Peters et al. 2003), drugs (van VugtLussenburg et al. 2007), and xenobiotics (Whitehouse et al. 2008) contained mutations that are not located in the active site.

Substrate and catalytic promiscuities are believed to be hallmark characteristics of primitive enzymes, serving as evolutionary starting points from which greater specificity is acquired following application of selective pressures (Khersonsky et al. 2006). It was proposed that the evolution of a new function is driven by mutations that have little effect on the native function but large effects on the promiscuous functions that serve as the starting point (Aharoni et al. 2005). Here we propose an alternative view of P450 evolution by which bacterial P450 enzymes acquire a new catalytic activity through mutations besides the crucial catalytic residues of the substrate binding region, substrate channel, and active site. This hypothesis may also provide clues to explain how P450 enzymes show broad substrate specificity, a characteristic that is specific to the P450 enzymes (Guengerich 2001). Catalytic promiscuity of bacterial P450s, at least CYP102A1, seems to be intrinsic to P450s, although the mechanisms by which the mutations contribute to the new activity are difficult to rationalize.

Here we report the presence of diverse natural variants of CYP102A1 within a species of B. megaterium. Phylogenetic analyses suggest that the CYP102A1 gene evolves more rapidly than the rRNA gene locus. While key catalytic residues in the substrate channel and active site are retained, several specific residues for frequent mutation were found. Although there were no apparent variations in hydroxylation activity towards myristic acid $\left(\mathrm{C}_{14}\right)$ and palmitic acid $\left(\mathrm{C}_{16}\right)$, the hydroxylation rates of lauric acid $\left(\mathrm{C}_{12}\right)$ by the variants varied in the range of $>25$-fold. Furthermore, catalytic activities of the variants are promiscuous towards non-natural substrates including human P450 substrates. These results suggest that bacterial P450 enzymes can acquire new catalytic activities through site-specific mutations distal to the active site. As these natural variants show similar activities as human P450 enzymes, they can be developed as industrial enzymes for cost-effective and scalable production of fine chemicals including drugs and their metabolites. Combined with rational design and directed evolution, the catalytic promiscuity of the self-sufficient CYP102A1 enzyme can be useful for extending their application in several fields of biotechnology.

\section{Additional material}

Additional file 1: Amino acid sequence alignment of CYP102A1 and its variants. CYP102A1 variants are arranged in order corresponding to the molecular phylogeny (Figure 1a) as indicated by the simplified schematic to the left of the amino acid alignment. Secondary structures are shown below the CYP102A1 variant sequences: $\alpha$-helices, red; $\beta$-sheets, blue. Binding sites of cofactors are shown: heme (yellow), FMN (dark blue), and FAD (gray).

Additional file 2: Distribution of hydroxylated products of fatty acids by CYP102A1 variants. Regioselectivity of the hydroxylated products of fatty acids at positions $\omega-1, \omega-2$, and $\omega-3$ was determined. Additional file 3: Enzymatic activities of the reductase domains of CYP102A1 variants. Assays for reductase domain-dependent electron transfer to exogenous electron acceptors (ferricyanide or cytochrome c) were performed.

\section{List of abbreviations}

P450 or CYP: Cytochrome P450s; CYP102A1: P450 BM3; IPTG: isopropyl- $\beta-D-$ thiogalactopyranoside; $\delta$-ALA: $\delta$-aminolevulinic acid; NADPH: reduced $\beta$ nicotinamide adenine dinucleotide phosphate; BSTFA: N,O-bis(trimethylsilyl) trifluoroacetamide; KCCM: Korean Culture Center of Microorganisms; KCTC: Korean Collection for Type Cultures; ATCC: American Type Microbiology; IFO: 
Institute of Fermentation, Osaka; PCR: polymerase chain reaction; ITS: intergenic sequence; $K_{d}$ : dissociation constants; 7-EC: 7-ethoxycoumarin; 7-EFC: 7-ethoxy-4-trifluoromethylcoumarin.

\section{Acknowledgements}

We thank Dr. Walter L. Miller (University of California San Francisco) and Dr. F. Peter Guengerich (Vanderbilt University) for discussions and comments on the manuscript. This work was supported by the $21 \mathrm{C}$ Frontier Microbial Genomics and the Application Center Program of the Ministry of Education, Science and Technology (MEST) of the Republic of Korea; Mid-career Researcher Program [Grant 2010-0027685], NRF (National Research Foundation), MEST of the Republic of Korea; and the Second Stage BK21 Project from the MEST of the Republic of Korea.

\section{Author details}

'School of Biological Sciences and Technology, Chonnam National University, Gwangju 500-757, Republic of Korea. ${ }^{2}$ Systems Microbiology Research Center, Korea Research Institute of Bioscience and Biotechnology, Daejeon 305-806, Republic of Korea. ${ }^{3}$ Department of Biochemistry, College of Veterinary Medicine, Chonnam National University, Gwangju 500-757, Republic of Korea.

\section{Authors' contributions}

JYK carried out the molecular genetic studies and the assay of fatty acid hydroxylation. SYK carried out the molecular genetic studies and the assay of fatty acid hydroxylation. DK participated in the sequence alignment and performed the statistical analysis. DHK carried out the molecular genetic studies and the assay of fatty acid hydroxylation. SMS carried out the molecular genetic studies and the assay of fatty acid hydroxylation. SHP carried out the assay of human drug substrate oxidation. KHK carried out the assay of human drug substrate oxidation. $\mathrm{HCJ}$ conceived of the study and participated in the design of the study. JGP participated in the design of the study. YHJ conceived of the study and participated in the design of the study. YTC participated in the design of the study. HZC participated in the design of the study. TA participated in the design of the study. CHY conceived of the study, participated in its design and coordination and wrote the manuscript. All authors read and approved the final manuscript.

\section{Authors' information}

$\mathrm{CHY}$ received a Ph.D. from Korea Advanced Institute of Science and Technology (Korea) with a major in biochemistry at 1990. Under the supervision of Prof. Hyoungman Kim, his thesis work focused on the protein interactions with phospholipids. Thereafter, he pursued post-doctoral studies with Prof. F. Peter Guengerich at Vanderbilt University (Nashville, TN, USA), where he studied human P450 enzymes. During 1992-2004, he took a position as a Professor at Paichai University (Daejeon, Korea). In 2004 he joined Chonnam National University (Gwangju, Korea) as a Professor at the School of Biological Sciences and Technology. His current research interests include the use of bacterial P450 enzymes as novel biocatalysts and their use in the production of drug metabolites.

\section{Competing interests}

The authors declare that they have no competing interests.

\section{Received: 13 January 2010 Accepted: 28 March 2011} Published: 28 March 2011

\section{References}

Aharoni A, Gaidukov L, Khersonsky O, McQ Gould S, Roodveldt C, Tawfik DS (2005) The 'evolvability' of promiscuous protein functions. Nat Genet 37:73-76

Altschul SF, Gish W, Miller W, Myers EW, Lipman DJ (1990) Basic local alignment search tool. J Mol Biol 215:403-410

Atrakchi AH (2009) Interpretation and considerations on the safety evaluation of human drug metabolites. Chem Res Toxicol 22:1217-1220

Bernhardt R (2006) Cytochromes P450 as versatile biocatalysts. J Biotechnol 124:128-145

Boddupalli SS, Estabrook RW, Peterson JA (1990) Fatty acid monooxygenation by cytochrome P-450BM-3. J Biol Chem 265:4233-4239
Eiben S, Bartelmas H, Urlacher VB (2007) Construction of a thermostable cytochrome P450 chimera derived from self-sufficient mesophilic parents. Appl Microbiol Biotechnol 75:1055-1061

Farinas ET, Schwaneberg U, Glieder A, Arnold FH (2001) Directed evolution of a Cytochrome P450 monooxygenase for alkane oxidation. Adv Synth Catal 343:601-606

Girvan HM, Levy CW, Williams P, Fisher K, Cheesman MR, Rigby SE, Leys D, Munro AW (2010) Glutamate-haem ester bond formation is disfavoured in flavocytochrome P450 BM3: characterization of glutamate substitution mutants at the haem site of P450 BM3. Biochem J 427:455-466

Guengerich FP (2001) Common and uncommon cytochrome P450 reactions related to metabolism and chemical toxicity. Chem Res Toxicol 14:611-650

Guengerich FP (2003) Cytochromes P450, drugs, and diseases. Mol Interv 3:194-204

Guengerich FP (2005) Human Cytochrome P450 Enzymes. In: Ortiz de Montellano PR (ed) Cytochrome P450: Structure, Mechanism, and Biochemistry. Kluwer Academic/Plenum Publishers, New York pp 377-530

Gürtler V (1999) The role of recombination and mutation in 16S-23S rDNA spacer rearrangements. Gene 238:241-252

Gustafsson MC, Roitel O, Marshall KR, Noble MA, Chapman SK, Pessegueiro A, Fulco AJ, Cheesman MR, von Wachenfeldt C, Munro AW (2004) Expression, purification, and characterization of Bacillus subtilis cytochromes P450 CYP102A2 and CYP102A3: flavocytochrome homologues of P450 BM3 from Bacillus megaterium. Biochemistry 43:5474-5487

Huang N, Agrawal V, Giacomini KM, Miller WL (2008) Genetics of P450 oxidoreductase: sequence variation in 842 individuals of four ethnicities and activities of 15 missense mutations. Proc Natl Acad Sci USA 105:1733-1738

Johnson MD, Zuo H, Lee KH, Trebley JP, Rae JM, Weatherman RV, Desta Z, Flockhart DA, Skaar TC (2004) Pharmacological characterization of 4-hydroxy$\mathrm{N}$-desmethyl tamoxifen, a novel active metabolite of tamoxifen. Breast Cancer Res Treat 85:151-159

Kelly SL, Kelly DE, Jackson CJ, Warrilow AG, Lamb DC (2005) The Diversity and Importance of Microbial Cytochrome P450. in: P.R. Ortiz de Montellano (ed.), Cytochrome P450: Structure, Mechanism, and Biochemistry. Kluwer Academic/Plenum Publishers, New York pp 585-617

Khersonsky O, Roodveldt C, Tawfik DS (2006) Enzyme promiscuity: evolutionary and mechanistic aspects. Curr Opin Biotechnol 10:498-508

Kim DH, Ahn T, Jung HC, Pan JG, Yun CH (2009) Generation of the human metabolite piceatannol from the anticancer-preventive agent resveratrol by bacterial cytochrome P450 BM3. Drug Metab Dispos 37:932-936

Kim DH, Kim KH, Isin EM, Guengerich FP, Chae HZ, Ahn T, Yun CH (2008a) Heterologous expression and characterization of wild-type human cytochrome P450 1A2 without conventional N-terminal modification in Escherichia coli. Protein Expr Purif 57:188-200

Kim DH, Kim KH, Kim DH, Liu KH, Jung HC, Pan JG, Yun CH (2008b) Generation of human metabolites of 7-ethoxycoumarin by bacterial cytochrome P450 BM3. Drug Metab Dispos 36:2166-2170

Kim DH, Kim KH, Kim D, Jung HC, Pan JG, Chi YT, Ahn T, Yun CH (2010) Oxidation of human cytochrome P450 1A2 substrates by Bacillus megaterium cytochrome P450 BM3. J Mol Catal B: Enzym 63:179-187

Kim KH, Kang JY, Kim DH, Park SH, Park SH, Kim D, Park KD, Lee YJ, Jung HC, Pan JG, Ahn T, Yun CH (2011) Generation of human chiral metabolites of simvastatin and lovastatin by bacterial CYP102A1 mutants. Drug Metab Dispos 39:140-150

Kitazume T, Haines DC, Estabrook RW, Chen B, Peterson JA (2007) Obligatory intermolecular electron-transfer from FAD to FMN in dimeric P450BM-3. Biochemistry 46:11892-11901

Leclercq L, Cuyckens F, Mannens GS, de Vries R, Timmerman P, Evans DC (2009) Which human metabolites have we MIST? Retrospective analysis, practical aspects, and perspectives for metabolite identification and quantification in pharmaceutical development. Chem Res Toxicol 22:280-293

Lentz O, Li QS, Schwaneberg U, Lutz-Wahl S, Fischer P, Schmid RD (2001) Modification of the fatty acid specificity of cytochrome P450 BM-3 from Bacillus megaterium by directed evolution: a validated assay. J Mol Catal B: Enzym 15:123-133

Lewis DF, Watson E, Lake BG (1998) Evolution of the cytochrome P450 superfamily: sequence alignments and pharmacogenetics. Mutat Res 410:245-270

Li H, Poulos TL (1997) The structure of the cytochrome P450BM-3 haem domain complexed with the fatty acid substrate, palmitoleic acid. Nat Struct Biol 4:140-146 
Ni Y, Wan D, He K (2008) 16 rDNA and 16S-23S internal transcribed spacer sequence analyses reveal inter- and intraspecific Acidithiobacillus phylogeny. Microbiology 154:2397-2407

Noble MA, Miles CS, Chapman SK, Lysek DA, MacKay AC, Reid GA, Hanzlik RP, Munro AW (1999) Roles of key active-site residues in flavocytochrome P450 BM3. Biochem J 339:371-379

Omura T, Sato R (1964) The carbon monoxide-binding pigment of liver microsomes. II. Solubilization, purification, and properties. J Biol Chem 239:2379-2385

Park SH, Kim DH, Kim D, Kim DH, Jung HC, Pan JG, Ahn T, Kim D, Yun CH (2010) Engineering bacterial cytochrome P450 BM3 into a prototype with human P450 enzyme activity using indigo formation. Drug Metab Dispos 38:732-739

Peters MW, Meinhold P, Glieder A, Arnold FH (2003) Regio- and enantioselective alkane hydroxylation with engineered cytochromes P450 BM-3. J Am Chem Soc 125:13442-13450

Porwal S, Lal S, Cheema S, Kalia VC (2009) Phylogeny in aid of the present and novel microbial lineages: Diversity in Bacillus. PLoS One 4:e4438

Ravichandran KG, Boddupalli SS, Hasermann CA, Peterson JA, Deisenhofer J (1993) Crystal structure of hemoprotein domain of P450BM-3, a prototype for microsomal P450's. Science 261:731-736

Ruettinger RT, Wen LP, Fulco AJ (1989) Coding nucleotide, 5' regulatory, and deduced amino acid sequences of P-450BM-3, a single peptide cytochrome P-450:NADPH-P-450 reductase from Bacillus megaterium. J Biol Chem 264:10987-10995

Sawayama AM, Chen MK, Kulanthaivel P, Kuo MS, Hemmerle H, Arnold FH (2009) A panel of cytochrome P450 BM3 variants to produce drug metabolites and diversify lead compounds. Chemistry 15:11723-11729

Seifert A, Vomund S, Grohmann K, Kriening S, Urlacher VB, Laschat S, Pleiss J (2009) Rational design of a minimal and highly enriched CYP102A1 mutant library with improved regio-, stereo- and chemoselectivity. Chembiochem 10:853-861

Stjernschantz E, van Vugt-Lussenburg BM, Bonifacio A, de Beer SB, van der Zwan G, Gooijer C, Commandeur JN, Vermeulen NP, Oostenbrink C (2008) Structural rationalization of novel drug metabolizing mutants of cytochrome P450 BM3. Proteins 71:336-352

Thompson JD, Gibson TJ, Plewniak F, Jeanmougin F, Higgins DG (1997) The CLUSTAL_X windows interface: flexible strategies for multiple sequence alignment aided by quality analysis tools. Nucleic Acids Res 25:4876-4882

van Vugt-Lussenburg BM, Stjernschantz E, Lastdrager J, Oostenbrink C, Vermeulen NP, Commandeur JN (2007) Identification of critical residues in novel drug metabolizing mutants of cytochrome P450 BM3 using random mutagenesis. J Med Chem 50:455-461

Whitehouse CJ, Bell SG, Tufton HG, Kenny RJ, Ogilvie LC, Wong LL (2008) Evolved CYP102A1 (P450BM3) variants oxidise a range of non-natural substrates and offer new selectivity options. Chem Commun (Camb) 28:966-968

Whitehouse CJ, Bell SG, Yang W, Yorke JA, Blanford CF, Strong AJ, Morse EJ, Bartlam M, Rao Z, Wong LL (2009) A highly active single-mutation variant of P450BM3 (CYP102A1). Chembiochem 10:1654-1656

Williams JA, Hyland R, Jones BC, Smith DA, Hurst S, Goosen TC, Peterkin V, Koup JR, Ball SE (2004) Drug-drug interactions for UDPglucuronosyltransferase substrates: a pharmacokinetic explanation for typically observed low exposure (AUCi/AUC) ratios. Drug Metab Dispos 32:1201-1208

Woese CR, Kandler O, Wheelis ML (1990) Towards a natural system of organisms: proposal for the domains Archaea, Bacteria, and Eucarya. Proc Natl Acad Sci USA 87:4576-4579

Yun CH, Kim KH, Kim DH, Jung HC, Pan JG (2007) The bacterial P450 BM3: a prototype for a biocatalyst with human P450 activities. Trends Biotechnol 25:289-298

Yun CH, Yim SK, Kim DH, Ahn T (2006) Functional expression of human cytochrome P450 enzymes in Escherichia coli. Curr Drug Metab 7:411-429

doi:10.1186/2191-0855-1-1

Cite this article as: Kang et al:: Characterization of diverse natural variants of CYP102A1 found within a species of Bacillus megaterium. AMB Express 2011 1:1.

\section{Submit your manuscript to a SpringerOpen ${ }^{\mathcal{O}}$ journal and benefit from:}

- Convenient online submission

- Rigorous peer review

- Immediate publication on acceptance

- Open access: articles freely available online

- High visibility within the field

- Retaining the copyright to your article

Submit your next manuscript at $\gg$ springeropen.com 